\title{
Experimental modification of vitellogenesis in Japanese quail by trypan blue in vivo
}

\author{
K D'Herde, F Roels \\ Department of Human Anatomy and Embryology, Godshuizenlaan, \\ 4, University of Ghent, Ghent, Belgium
}

(Received 20 July, 1993; accepted 5 October 1993)

\begin{abstract}
Summary - Ovaries of adult Japanese quails were exposed in vivo to the acid bisazo dye trypan blue (TB) which binds to plasma albumin, the plasma precursor of the yolk protein $\alpha$-livetin. By a combination of fluorescence microscopy and electron microscopy $\alpha$-livetin could be localized in the subdroplets of intermediary and yellow yolk spheres. Trypan blue alters vitellogenesis in the nondisc region of follicles in rapid growth in a reversible and dose-dependent way. Less yolk is produced over $24 \mathrm{~h}$ and its morphology is different when compared to controls. This yolk is similar to yolk of the germinal disc region where viteliogenesis is known to be inhibited physiologically. Several ultrastructural features of the germinal disc region are also found in the non-disc region of TBexposed follicles. Our results suggest that the morphology of yellow yolk is linked to the rate of deposition. We propose that the inhibitory action of TB on vitellogenesis can be explained by a defective receptor-ligand dissociation in endosomes.
\end{abstract}

$\alpha$-livetin / vitellogenesis / quail / receptor-mediated endocytosis / tracer

Résumé - Modification expérimentale de la vitellogenèse par injection in vivo de bleu trypan chez la caille japonaise. Des ovaires de cailles japonaises pondeuses ont été exposés in vivo au bleu trypan. Après injection sous-cutanée ce colorant s'attache à l'albumine, lequel est le précurseur plasmatique de l' $\alpha$-livetine, une des protéines constituant le jaune d'œuf. En combinant la microscopie par fluorescence et la microscopie électronique, nous avons pu localiser l' $\alpha$-livetine dans les sphères vitellines compactes des vacuoles de vitellus primordial et dans les grains sphériques des plaquettes vitellines jaunes. Nous montrons que le bleu trypan modifie la vitellogenèse dans la région végétative des follicules en croissance finale et ceci d'une façon réversible et proportionnelle à la dose utilisée. La couche de vitellus produite en 24 h est moins épaisse comparée aux contrôles. Les plaquettes vitellines sont d'une morphologie semblable à celles du disque germinatif, où il a été démontré que la vitellogenèse est inhibée physiologiquement. Différentes caractéristiques ultrastructurales du disque germinatif sont retrouvées dans la région végétative des follicules exposés au bleu trypan. Nos résultats indiquent que la morphologie du vitellus jaune est liée à la vitesse de sa formation. L'action inhibitrice du bleu trypan est expliquée par blocage de la dissociation des complexes formés entre récepteurs et protéines vitellines au cours de l'endocytose.

$\alpha$-livetine / vitellogenèse / caille / endocytose par récepteurs / traceur 


\section{INTRODUCTION}

In studies on vitellogenesis there is a substantial gap between the detailed biochemical analysis of yolk components and the rarity of morphological information on the ultrastructural localization of different yolk components. Our knowledge about localization of yolk components is limited to phosphoproteins: phosvitin and lipovitellin (Bellairs et al, 1972); the very low density lipoproteins (Perry et al, 1978a, 1978b, 1979, 1985); and the triglycerides (Callebaut et al, 1991). The subcellular localization of $\alpha$-livetin, one of the water-soluble yolk proteins, remains to be understood (Guraya, 1989). Several authors demonstrated that plasma albumin is the precursor of the yolk-protein $\alpha$-livetin (Williams, 1962; Mclndoe and Culbert, 1979).

Rawson (1943) was the first to indicate that the acid bisazo dye trypan blue (TB) is strongly bound to plasma albumin after injection. This property of TB was used in our experiments to study the subcellular localization of $\alpha$-livetin in yolk. TB has been used repeatedly in the past to study exogenous vitellogenesis of invertebrates (Ramamurty, 1964; Telfer and Anderson, 1968; Anderson and Telfer, 1970; Engels, 1973; Wajc et al, 1977; Telfer et al, 1982) and vertebrates (Korfsmeier, 1966). More recently the technique was used to study ooplasmic segregation in vertebrates (Callebaut, 1983, 1984, 1985, 1987; Callebaut et al, 1981; Callebaut and Vakaet, 1981; Callebaut and Sijens, 1985; Callen, 1986; Danilchik and Denegre, 1991). The TB exclusion test is an accepted method of assessing the viability of cells in culture.

\section{MATERIAL AND METHODS}

\section{Experimental procedure}

We examined pediculated ovarian follicles of daily-laying Japanese quail (Coturnix coturnix japonica) reared under continuous artificial light illumination. We examined the 5 largest yellow postlampbrush follicles in rapid growth phase $\left(F_{1}, F_{2}, F_{3}, F_{4}\right.$ and $F_{5}$, according to the nomenclature of Gilbert, 1971) and white postlampbrush follicles in intermediary yolk formation (according to the staging of Callebaut, 1974). Twenty-five animals received a single subcutaneous injection of a $1 \%(w / v)$ TB (Serva $n r$ 37252, Heidelberg, Germany) in Ringer solution $24 \mathrm{~h}$ before the fixation procedure. This time interval makes it possible to appreciate the quantity of yolk produced after the injection in comparison to the physiological situation (Callebaut, 1983). Comparison of the diameters of yellow follicles of quails laying at a circadian rhythm reveals the daily accumulated yolk layer during the rapid growth phase. Shortly before ovulation the largest yellow-yolked follicles has a diameter of approximately $18 \mathrm{~mm}$, the next follicle has a diameter of $14 \mathrm{~mm}$, indicating an increase in diameter by yolk accumulation of $4 \mathrm{~mm}$ during the last day before ovulation. These data were confirmed by autoradiographic experiments in which quails received daily injections of radioactive tracers; the distance between labelled yolk layers in a follicle represents the yolk accumulation during a certain 24$h$ period (for example, $F_{3} \rightarrow F_{2}$ ) (Callebaut, 1983).

Doses of $1,0.7$ and $0.3 \mathrm{ml}$ of the $1 \%$ solution were compared. Although these doses would not adversely affect subsequent embryonal development (Callebaut et al, 1981), a harmful effect was recently demonstrated after in vitro TB exclusion test of mouse oocytes (Nijs et al, 1992). Ten untreated birds and 5 birds receiving the same volume of Ringer solution were used as controls. 


\section{Fluorescence microscopy}

The tissues were fixed for $24 \mathrm{~h}$ at room temperature in Heidenhain's Susa and embedded in paraffin; 6- $\mu \mathrm{m}$ sections were mounted in a fluorescence-free medium (Fluoromount, Gurr, BDH chemicals Ltd Poole, England). The sections were examined under a Leitz Orthoplan microscope equipped with a HBO 100 high-pressure mercury lamp and an incident-light Ploem Opak illuminator. A 4-nm BG 38 red suppression filter and a 2-mm KG1 heat absorption filter were placed in the lamp housing. Blue excitation filters $2 \times$ SP 490 in combination with a chromatic beam splitter (CBS) with a cut-off at $510 \mathrm{~nm}$ (filter setting No 3 ) were used (Harrison et al, 1981). The chemical interaction between TB and plasma albumin results in a red fluorescence (Udenfriend, 1962) and permits the detection of TB-marked yolk with high sensitivity. Control ovaries only exhibited a green background fluorescence. Nomarski interference microscopy of paraffin sections was used to demonstrate the shape and internal structure of yolk.

\section{Electron microscopy}

Several authors have used TB as a tracer in electron microscopy (Trump, 1961; Schmidt, 1962; Lloyd et al, 1968). The tissues were fixed in a compound-aldehyde fixative containing glutaraldehyde, paraformaldehyde, acroleine and DMSO as described previously (D'Herde and Vakaet, 1992). After an initial fixation in toto over $3 \mathrm{~d}$, the follicle wall with adherent yolk of the vegetative pole was excised and fixation was continued for another $3 \mathrm{~d}$ at $4^{\circ} \mathrm{C}$. The tissue was rinsed in cacodylate buffer, post-fixed in $2 \%$ osmium tetroxide in buffer for $5 \mathrm{~h}$ at $4^{\circ} \mathrm{C}$ and embedded in LX (Ladd, Burlington, V, USA). Semithin sections were contrasted with toluidine blue. Ultrathin sections were stained with uranyl acetate and lead citrate.

\section{RESULTS}

We will report our results per stage of folliculogenesis. Definition of these stages was given in a previous paper (D'Herde and Vakaet, 1992).

\section{Fluorescence microscopy}

The postlampbrush follicles in intermediary yolk formation typically show a TB-induced fluorescence apically in their granulosa cells. In the oocyte, positivity is found on intermediary yolk vacuoles beneath the cortex (fig 1a).

Comparison with toluidine-blue-stained semithin sections of the same material reveals that the fluorescence is localized on the dense subdroplets of the intermediary yolk vacuoles (fig $1 \mathrm{~b}$ ). No inhibition on intermediary yolk formation is seen, even with the highest doses of TB.

In the postlampbrush follicles in yellowyolk formation fluorescence is no longer localized inside the granulosa cells, but between them; this disappears during the last day before ovulation. The developing vitelline membrane is strongly marked. In the oocyte, fluorescence was found in discrete masses inside yellow-yolk spheres (fig 2). As the first intraoocytal marking of yolk takes place $20 \mathrm{~min}$ after injection of the tracer (Callebaut et al, 1981), the distance from the deepest marked yolk layer to the surface of the oocyte equals the yolk production during $24 \mathrm{~h}$, ie the time between injection of the tracer and decapitation of the animal. The effect of $0.3 \mathrm{ml}$ TB is reversible in vivo. After the deposition of a layer of yolk with aberrant morphology a superficial layer of normal morphology is deposited. In this final yolk layer fluorescence is found as usual on numerous small globules inside the yellow-yolk spheres while the abnormal layer is localized deeper inside the oocyte (figs $3,4 \mathrm{~b}$ ). In the experiments with the use of 1 and $0.7 \mathrm{ml}$ TB solution we found a thickness of 100 and 200 $\mu \mathrm{m}$ respectively; in controls a layer of sev- 
eral $\mathrm{mm}$ is produced in the same time interval (Callebaut, 1974). A dose of $0.3 \mathrm{ml}$ does not significantly reduce the total yolk production over $24 \mathrm{~h}$ (fig $4 \mathrm{a}, \mathrm{b}$ ). A distinct inverse relation was present between the tracer dose injected, the diameter of the labelled yolk spheres and the number of discrete fluorescent masses per yolk sphere (fig 4b,c,d).

\section{Semi-thin sections and electron microscopy}

As TB seems to modify only the vitellogenesis of postlampbrush follicles in yellowyolk formation, only this category of follicles was investigated ultrastructurally.

\section{Yolk}

The observations made by fluorescence microscopy were confirmed. After $0.7-1 \mathrm{ml}$ $T B$, yolk spheres were formed with a smaller diameter and containing few, large subdroplets; some subdroplets having a signet ring form, as can be observed in the disc region of controls (fig 5 ). The discrete fluorescent masses clearly correspond to the electron-dense subdroplet structures.

\section{The surface of the oocyte}

At the surface of TB-marked follicles $(1 \mathrm{ml}$ and $0.7 \mathrm{ml}$ ) we found very few and smaller coated vesicles when compared to the controls, where numerous coated vesicles in the $250-300 \mathrm{~nm}$ range were present (fig 6).

\section{Vitelline membrane}

The vitelline membrane after TB administration $(1$ and $0.7 \mathrm{ml})$ is thicker than in the controls and its components present a swollen appearance (compare figs $6 a$ and $b$ ).

\section{Granulosa}

In the basal spaces of the granulosa layer of $F_{1}, F_{2}$ and $F_{3}$ follicles over the non-disc region we found clumps of electron-dense material (fig 6a), as have been described in the disc region in physiological conditions at all stages and in the non-disc region of mature follicles (Perry et al, 1978c).

Fig 1. Postlampbrush follicle in intermediary yolk formation, $0.7 \mathrm{ml} \mathrm{TB} 1 \%$ by: a) fluorescence microscopy; b) $2 \mu \mathrm{m}$ LX-section, toluidine blue staining. Comparison of $\mathbf{a}$ and $\mathbf{b}$ shows that the tracer is confined to the dense subdroplets of the intermediary yolk formed after the injection; note the apical fluorescence in the granulosa $(G)$ in a bars: $10 \mu \mathrm{m}$.

Fig 2. Postlampbrush follicle in yellow-yolk formation $\left(F_{1}\right)$, non-disc region, $0.7 \mathrm{ml}$ TB $1 \%$. TB-induced red fluorescence in the vitelline membrane (arrowheads) and in subdroplets of yellow-yolk spheres (arrows). Note the absence of fluorescence in the granulosa (G) cell layer; bar: $20 \mu \mathrm{m}$.

Fig 3. Postlampbrush follicle in yellow-yolk formation $\left(F_{5}\right), 0.3 \mathrm{ml} \mathrm{TB} 1 \%, 6 \mu \mathrm{m}$ paraffin section. a) Composite image of the 3 distinct zones of yolk formation with the most recently formed yolk found near the granulosa (arrowheads); the older yolk is pushed more centrally; $X$ : zone of yolk formed before the injections; $Y$ : zone of yolk formed shortly after the TB injection; $Z$ : zone of yolk formed shortly before fixation; the yolk spheres of the intermediate zone $(Y)$ are on average smaller and contain larger subdroplets (arrows); Nomarski interference microscopy; bar: $100 \mu \mathrm{m}$. b) Fluorescence microscopy, detail of the composite image at the edge of zone $Y$ and $Z$; irregular smaller yolk spheres with a few large subdroplets (arrowheads); large yolk sphere with normal configuration (arrow); bar: $20 \mu \mathrm{m}$. 


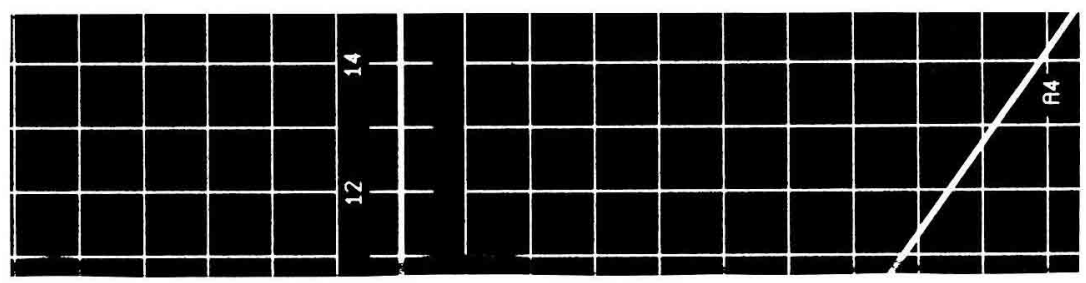

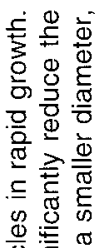

음 흥 잏

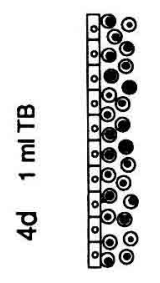

ㄴㅇㅇ 홍믐

응 토

인응 흔

눅 里

佥

훙ㅎㅇ

등등 흔

웡은

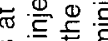

क品

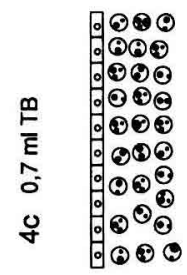

बे $\bar{\Phi}$

응

产 $\frac{\omega}{5} 0 \overline{0}$

ᄃㄷ⿺워

同卫

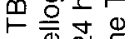

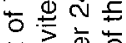

ปั

志就

我

焉栲

뜽응 운

후응

을 중

E

융응

壱全苛兄

똥ㅎํ

홍

응 홍

일

言.

등

㳕志志

잏

产 वे

牙 듬 동

은

틍ㄷㅇ웡

등 흥

只

믄듕

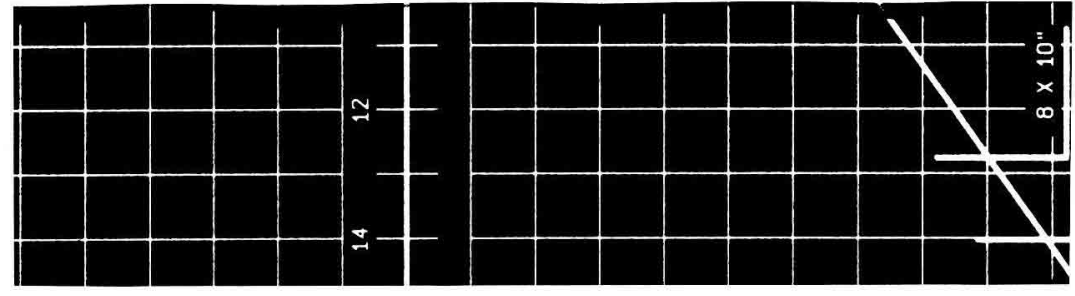



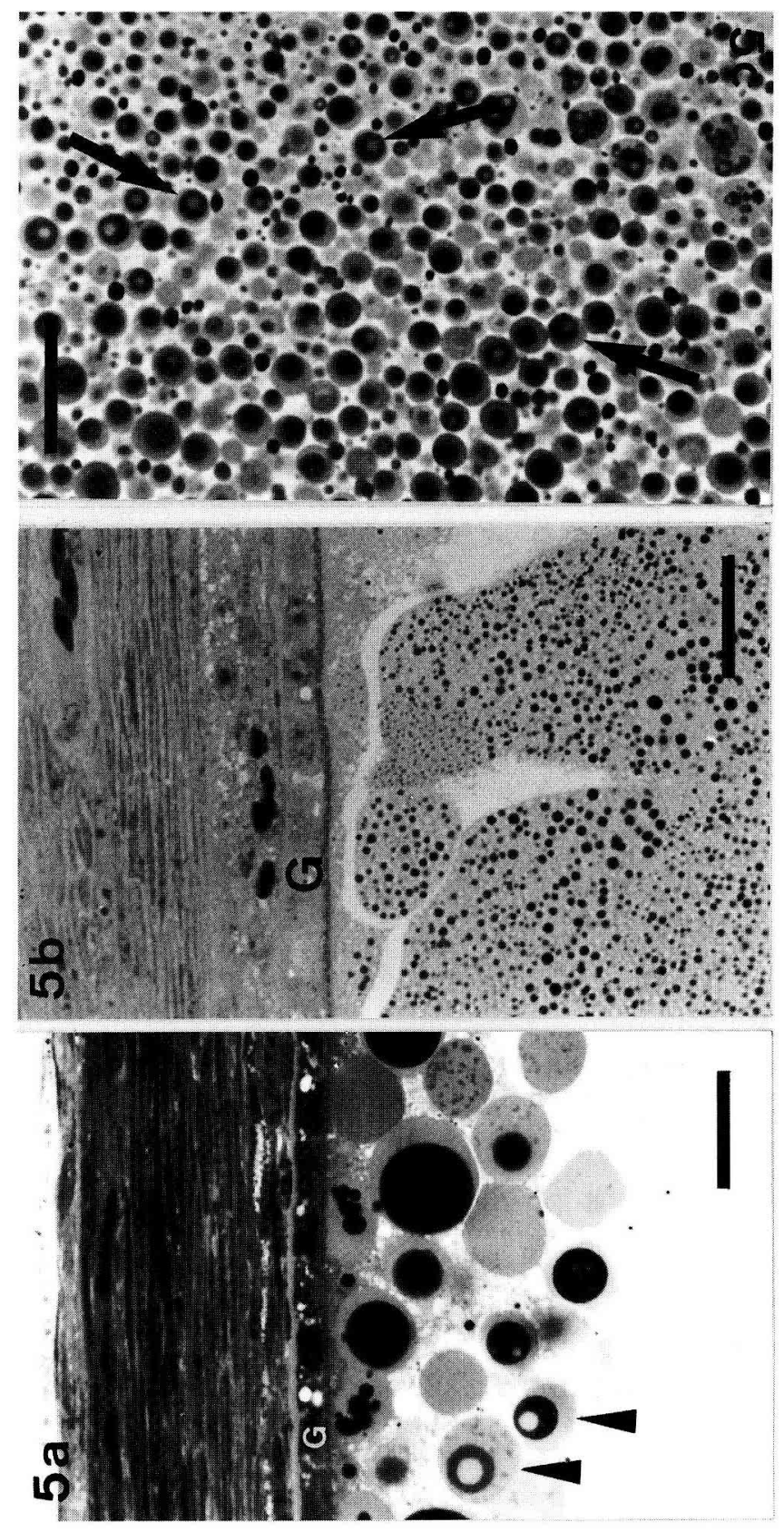

产的.

$>$ 응

苋 $\frac{\bar{\pi}}{\mathbb{\pi}}$

ष

돈

웅

트음

的完:

$\bar{\varepsilon} \overline{\mathrm{g}} \mathrm{g}$

-

을

음

인

员

它夏

눈

그용

我

훙응

क

$\Phi$ 든

满

$\stackrel{5}{5}$

흠

产 范

ᄃㅇ क

응 흥

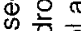

$\times$

के

至帝

N

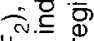

4

등.

훈흥

है o

응

홍ㅎㅇ

응응 홍

文这要

ड 3 के

O)

응

4 오잉

돈 은

흘

응 质

ह 3

픈

○㐫

0 등

เ० के

은 응 응 

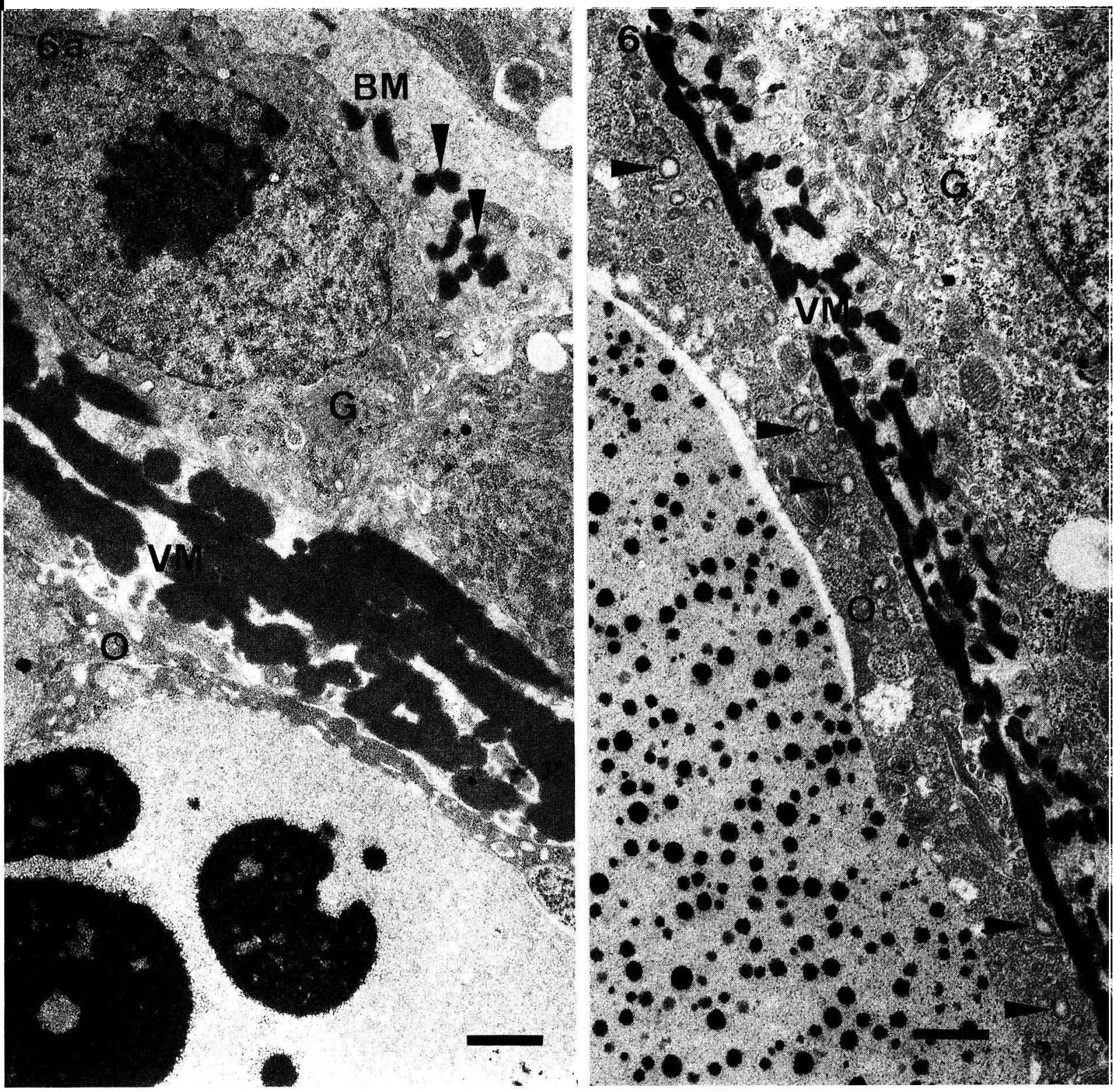

Fig 6. Postlampbrush follicle in yellow-yolk formation $\left(F_{1}\right)$, non-disc region. a) $0.7 \mathrm{ml}$ TB $1 \%$. Note the presence of electron-dense material in the basal membrane, especially concentrated at the junction of 2 granulosa cells (arrowheads), there are a few, small coated vesicles at the surface of the oocyte; b) Control animal. Numerous, large coated vesicles at the oocyte surface (arrowheads). Compare the size and number of the yolk subdroplets in $\mathbf{b}$ with those of the TB experiment in a. VM: vitelline membrane; BM: basal membrane; G: granulosa; O: oocyte; bars: $1 \mu \mathrm{m}$. 
These authors interpreted the accumulation of electron-dense material as resulting from the reduced rate of yolk uptake which is typical for the germinal disc region (Callebaut, 1974). In the experiments with $0.3 \mathrm{ml}$ TB the above-mentioned alterations were not noted.

\section{DISCUSSION}

The yolk component $\alpha$-livetin traced by TB was localized in the subdroplet structure of intermediary and yellow-yolk spheres. It is important to stress that this localization was not only found in the experiments where TB inhibited vitellogenesis, but also after the lowest dose where a temporary slowing down was followed by a normal pattern of yellow-yolk deposition. In this superficial layer where yellow-yolk spheres have a normal diameter and typical small subdroplets are numerous, TBfluorescence was present exclusively in the subdroplets. Moreover in the postlampbrush follicles in intermediary yolk formation where no inhibition was noted, the tracer was also confined to the subdroplets.

In the granulosa cells fluorescence is present only 16-24 $\mathrm{h}$ after injection, while intra-oocytal positivity is already detectable after 20 min (Callebaut et al, 1981). Thus the intracellular localization in the granulosa of the tracer is not a prerequisite for uptake by the oocyte; it simply reflects the high absorptive capacity of the granulosa during intermediary yolk formation as we previously demonstrated with horseradish peroxidase as a tracer (D'Herde and Vakaet, 1992).

That TB is avidly taken up by the oocyte, while inhibiting vitellogenesis, has been previously published for various invertebrates. In zebrafish oocytes TB also inhibits vitellogenesis while accumulating in the zona radiata (Korfsmeier, 1966). Our study is the first to report the intraoocytal accumulation of TB and simultaneous inhibitory effect on vitellogenesis in higher animals. The reversibility of this inhibition with the use of a single low dose was not previously shown in in vivo experiments.

By combining fluorescence microscopy and electron microscopy we could specify that the morphology of this aberrant yolk formation is similar to the type of yolk found in the germinal disc region as described by Bakst and Howarth (1977). It was shown by autoradiography that vitellogenesis is physiologically inhibited in the germinal disc region (Callebaut, 1974). Besides morphology of yolk, other features in the non-disc region of experimental follicles are similar to what is found physiologically in the disc region (Perry et al, 1978c): i) the accumulation of electron-dense material in the basal spaces of the granulosa layer; and ii) the structure of the surface layer of the oocyte, containing fewer, smaller coated vesicles indicating that the import of macromolecules by the oocyte is strongly reduced. These observations suggest that the difference in the morphology of yolk in the disc and non-disc regions is probably related to the rate of yolk deposition.

The mechanism by which TB interferes with endocytotic processes has been the subject of considerable speculation. Lloyd et al showed that TB inhibits lysosomal enzymes in vitro and postulated that the wellknown teratogenic, carcinogenic and trypanocidal activities are related to this enzyme inhibition (Lloyd et al, 1968). Anderson and Telfer proposed that in the moth Hyalophora cecropia TB binds to a follicle cell product necessary for induction of pinocytosis by the oocyte (Anderson and Telfer, 1970). They later concluded from their in vitro experiments that in TB-treated follicles an extraordinary amount of unutilized endocytotic elements accumulates in the 
oocyte cortex (Telfer et al, 1982). Electron microscopy revealed an abnormal cortical anatomy which is comparable to our findings: few coated pits and vesicles at the cell surface. Moreover, after reversion of the inhibition by injections of hemolymph proteins, swollen endosomes were found in the oocytal cortex. Such aberrant endosomal structures are also found in experiments with weak bases (also vital dyes) for which the mechanism of inhibition is known to be a defective receptor-ligand dissociation (Wolkoff et al, 1984). Recently it was shown that TB modulates receptorligand binding in rat heart homogenates (Gerstin et al, 1992). TB is also used to block phagocytosis of macrophages in in vivo experiments (Taradi et al, 1991). The rationale for its effect as an trypanocidal drug is still not fully elucidated, but it is remarkable that suramin with the same antiparasitic activity inhibits the fusion of endosomes with lysosomes (Ehlers, 1989). From our results and these recent data, the following model is proposed to explain the inhibitory effect of TB on yellow-yolk formation which is known to be mainly a process of receptor-mediated endocytosis (Perry et al, 1979). The dissociation between receptor and ligand in endosomes is prevented, resulting in recycling of fewer receptors to the oocytal membrane, which explains the presence of fewer, smaller coated vesicles at the oocyte surface. When receptor-ligand dissociation is prevented, endosomes cannot deliver their content to yolk spheres resulting eventually in aberrant endosomal structures. That viable mouse oocytes undergoing a TB exclusion test have a reduced ability to become fertilized (Nijs et al, 1992) should be further analysed in this context.

\section{ACKNOWLEDGMENTS}

This study was supported by grant 9.0027 .88 from the Belgian National Lottery. We are much indebted to B De Prest and MJ Slos for excellent technical assistance. We thank R Mortier for printing the photographs and $G$ Van Limbergen for preparation of the manuscript.

\section{REFERENCES}

Anderson LM, Telfer WH (1970) Trypan blue inhibition of yolk deposition - a clue to follicle cell function in the cecropia moth. J Embryol Exp Morphol 23, 35-52

Bakst MR, Howarth Jr B (1977) The fine structure of the hen's ovum at ovulation. Biol Reprod 17, 361-369

Bellairs R, Backhouse M, Evans RJ (1972) A correlated chemical and morphological study of egg yolk and its constituents. Micron 3 , 328-346

Callebaut M (1974) La formation de l'oocyte d'oiseau. Étude autoradiographique chez la caille japonaise (Coturnix coturnix japonica) pondeuse à l'aide de la leucine tritiée. Arch Biol (Brussels) 85, 201-233

Callebaut M (1983) The constituant oocytal layers of the avian germ and the origin of the primordial germ cell yolk. Arch Anat Microscop Morphol Exp 72, 199-214

Callebaut M (1984) Avian primordial germ cells contain yolk from the nucleus of Pander. IRCS Med Sci 21, 730-731

Callebaut $M$ (1985) Link between avian oogenesis and gastrulation: demonstration of a preembryonic fate map by trypan blue-induced fluorescence. IRCS Med Sci 13, 711-712

Callebaut M (1987) Ooplasmic localization and segregation in quail germs: fate of the four ooplasms. Arch Biol (Brussels) 98, 441-473

Callebaut M, Vakaet L (1981) Fluorescent yolk marking of the primary gonocytes in quail blastoderms by administration of trypan blue, during late oogenesis. IRCS Med Sci 9, 458

Callebaut M, Harrison F, Vakaet L (1981) Peripheral avian yolk assemblage and its persistence in the blastoderm, studied by trypan blue-induced fluorescence. Anat Embryol 163, 55-69

Callebaut M, Sijens RJ (1985) Trypan blueinduced fluorescence in adult quail oocytes during the prelampbrush and early lampbrush stage. IRCS Med Sci 13, 920-921 
Callebaut M, D'Herde K, Hermans N, Van Nassauw $L$ (1991) Localization and transport of lipids in the avian ovarian follicular layers and the structural relationship of theca and granulosa to the basement membrane. J Morphol 209, 143-163

Callen JC (1986) Differential pinocytosis and the origin of the animal-vegetal polarity in Xenopus laevis oocytes of growing or postspawning adult females. Biol Cell 57, 207-220

D'Herde K, Vakaet L (1992) Study of the yolk precursor transport in the avian ovary with the use of horseradish peroxidase. Int $J \mathrm{Dev}$ Biol 36, 435-438

Danilchik MV, Denegre JM (1991) Deep cytoplasmic rearrangements during early development in Xenopus laevis. Development (Camb) 111, 845-856

Ehlers D (1989) Side effects of the trypanocidal chemotherapeutics trypan blue and suramin. Angew Parasitol 30, 189-192

Engels W (1973) Das zeitliche und raumliche Muster der Dottereinlagerung in die Oocyte von Apis mellifica. $Z$ Zellforsch Mikrosk Anat 142, 409-430

Gerstin EH JR, Luong T, Ehlert FJ (1992) Heparin, dextran and trypan blue allosterically modulate muscarinic receptor binding properties and interfere with receptor-mediated inhibition of adenyl cyclase. J Pharmacol Exp Ther 263, 910-917

Gilbert AB (1971) The Ovary, In: Physiol and Biochem of the Domestic Fowl 3 (DJ Bell, BM Freeman, eds) Academic Press NY, 1209-1223

Guraya SS (1989) Ovarian Follicles in Reptiles and Birds. In: Zoophysiology, vol 24, Springer Verlag, Berlin

Harrisson F, Callebaut M, Vakaet L (1981) Microspectrographic analysis of trypan blueinduced fluorescence in oocytes of the Japanese quail. Histochemistry $72,563-578$

Korfsmeier KH (1966) Zur Genese des Dottersystems in der Oocyte von Brachydanio rerio - Autoradiografishe Untersuchungen. Z Zellforsch Mikrost Anat 71, 283-296

Lloyd JB, Beck F, Griffiths A, Parry LM (1968) The mechanism of action of acid bisazo dyes. Biological Council Symposium on the Interaction of Drugs and Subcellular Particles in Animal Cells (PN Campbell, ed) Churchill, London, 171-202
Mcindoe WM, Culbert J (1979) The plasma albumins and other livetin proteins in egg yolk of the domestic fowl. Int J Biochem 10, 659664

Nijs M, Van Blerk M, Van Steirteghem AC (1992) Activation of mouse oocytes, fertilization and development of mouse embryos in vitro after staining with trypan blue or fluorescein diacetate. Biotech Histochem 67, 351355

Perry MM, Evans AJ, Gilbert AB (1978a) A method to demonstrate very low density lipoprotein particles in the ovarian follicle of the domestic fowl. Micron 9, 237-245

Perry MM, Gilbert AB, Evans AJ (1978b) Electron microscope observations on the ovarian follicle of the domestic fowl during the rapid growth phase. J Anat 125, 379-392

Perry MM, Gilbert AB, Evans AJ (1978c) The structure of the germinal disc region of the hen's ovarian follicle during the rapid growth phase. J Anat 127, 379-392

Perry MM, Gilbert AB (1979) Yolk transport in the ovarian follicle of the hen: lipoprotein-like particles at the periphery of the oocyte in the rapid growth phase. J Cell Sci 39, 257-272

Perry MM, Gilbert AB (185) The structure of yellow yolk in the domestic fowl. J Ultrastruct Res 90, 313-322

Ramamurty PS (1964) On the contribution of the follicle epithelium to the deposition of yolk in the oocyte of panorpa communis (Mecoptera). Exp Cell Res 33, 601-605

Rawson RA (1943) The binding of T-1824 and structurally related diazo dyes by the plasmaproteins. Am J Physiol 138, 708-717

Schmidt W (1962) Licht-und electronenmicroskopische Untersuchungen uber die intrazellulare Verarbeitung von Vitalfarbstoffen. $Z$ Zellforsch Mikrosk Anat 58, 573-637

Taradi M, Urano M, Taradi S, Kukolja, Maruyma $Y$ (1991) Augmentation of mouse natural killer cell activity by combined hyperthermia and streptococal preparation, OK-432 (Picibanil) treatment. Int J Hyperthermia 7, 653-665

Telfer WH, Anderson LM (1968) Functional transformation accompanying the initiation of a terminal growth phase in the cecropia moth oocyte. Dev Biol 17, 512-535

Telfer WH, Huebner E, Smith DS (1982) The cell biology of vitellogenic follicles in Hyalo- 
phora and Rhodnius. In: Insect Ultrastructure Vol 1 (RC King, H Akai, eds) Plenum Press, NY, 118-149

Trump BF (1961) An electron microscope study of the uptake, transport, and storage of colloidal materials by the cells of the vertebrate nephron. J Uitrastruct Res 5, 291-310

Udenfriend S (1962) Fluorescence Assay in Biology and Medicine, Academic Press, NY

Wajc E, Bakker-Grunwald T, Applebaum WS (1977) Binding and uptake of trypan blue by developing oocytes of Locusta migratoria migratorioides. J Embryol Exp Morphol 37, 1-11

Williams $J(1962)$ Serum proteins and the livetins of hen's egg yolk. Biochem $J$ 83, 346355

Wolkoff AW, Klausner RD, Ashwell G, Harford J (1984) Intracellular segregation of asialoglycoproteins and their receptor: a prelysosomal event subsequent to dissociation of the ligand-receptor complex. J Cell Biol 98, 375381 